NBER WORKING PAPER SERIES

\title{
SEVENTY YEARS OF CENTRAL BANKING: THE BANK OF CANADA IN INTERNATIONAL \\ CONTEXT, 1935-2005
}

\author{
Michael D. Bordo \\ Angela Redish \\ Working Paper 11586 \\ http://www.nber.org/papers/w11586
NATIONAL BUREAU OF ECONOMIC RESEARCH
1050 Massachusetts Avenue
Cambridge, MA 02138
August 2005

Paper prepared for panel discussion, in honour of the 70th anniversary of the establishment of the Bank of Canada at the annual meetings of the Canadian Economics Association, May 2005, Hamilton Ontario. The authors wish to thank Robert Gateman for comments. The views expressed herein are those of the author(s) and do not necessarily reflect the views of the National Bureau of Economic Research.

(C)2005 by Michael D. Bordo and Angela Redish. All rights reserved. Short sections of text, not to exceed two paragraphs, may be quoted without explicit permission provided that full credit, including (C) notice, is given to the source. 
Seventy Years of Central Banking: The Bank of Canada in International Context, 1935-2005 Michael D. Bordo and Angela Redish

NBER Working Paper No. 11586

August 2005

JEL No. E58

\title{
ABSTRACT
}

On the seventieth birthday of the Bank of Canada, we evaluate the Bank's contribution to monetary policy in an international context. We focus on: the reasons for the establishment of the central bank in 1935, its unique record of floating in a sea of fixed currencies under Bretton Woods; its experience with the Great Inflation and monetarism; its pioneering adoption of inflation targeting; and recent innovations in the payments and the phasing out of reserve requirements.

\author{
Michael D. Bordo \\ Department of Economics \\ Rutgers University \\ New Brunswick, NJ 08901 \\ and NBER \\ bordo@econ.rutgers.edu \\ Angela Redish \\ Department of Economics \\ University of British Columbia \\ Vancouver, BC V6T 1Z1 \\ CANADA \\ anji@econ.ubc.edu
}


March 11, 1935, the Bank of Canada opened its doors. What did it see? An economy in turmoil and well-wishers from all sides of the political and economic spectrum that believed the Bank could solve their problems. Did it? What did the Bank do? We will leave aside important questions about the Bank's role in financial stability, currency management, and debt management, by focusing on the question of monetary policy and focus on the Bank's contribution in an international context: What did central banks in general do over the last 70 years, and where was Canada a notable innovator?

<insert Figure 1: Inflation Canada and the US, 1935-05 >

At the beginning of the twentieth century a monetary orthodoxy had been created, wherein a 'civilized' country had a monetary unit defined as a given weight of gold, and a central bank that managed the note issue and protected the value of the currency. These institutions were challenged by World War I, and especially the debts and reparations that lingered after the War, but the system was more or less re-established in the mid-1920s. By the early 1930s, the exigencies of the Great Depression led many countries to abandon the convertibility of their currency into gold, but this was widely seen as a transitory phenomenon and a return to some link to gold was anticipated.

During the Second World War (what Temin and others have called the later phase of the second Thirty Years War) exchange rates and foreign exchange - like many other prices and quantities - were administered by government fiat. At the conclusion of the war, at the famous hotel in Bretton Woods, New Hampshire, delegates from 44 countries designed a new international monetary regime. They established the IMF and World Bank; countries would gradually open up their current accounts, and currencies would become convertible; the US - which had in fact banned the holding of gold by private individuals - would maintain the convertibility of the dollar into gold at its traditional parity, and other countries would simply maintain convertibility of their currencies into US dollars: indirect gold convertibility. The gold standard that had provided a nominal anchor to the monetary system from the 1880 s to 1914 was reestablished, but the chain was now rather elastic (Redish, 1993). 
The Bretton Woods pact finally ended in 1973 when the US suspended the gold convertibility of the dollar. ${ }^{1}$ The subsequent decade is known for the "Great Inflation" which in Canada and the US peaked at the end of the decade at about 15\% (annualized). The early 1980s saw aggressive disinflation in both countries, and inflation rates have stabilized at around $2 \%$ in the majority of G7 countries in the last decade of the $20^{\text {th }}$ century.

Where does the Bank of Canada fit into this story? The behaviour of inflation is evidence of the important background fact that there can't be a completely idiosyncratic Canadian story - inflation rates, at least, performed more or less the same in Canada and the US. ${ }^{2}$ However, there can still be an important role played by the Bank of Canada - perhaps the Bank managed to minimize the negative consequences of inflation and disinflation for the Canadian economy? Perhaps Canadian policy led US policy? Perhaps Canadian policy was implemented more efficiently? Again, we focus on only a piece of the answer - on the half dozen issues where Canada - for better or worse - was slightly out of step (ahead or behind!) with international experience:

- Lack of a central bank in the early years;

- The floating rate in the Bretton Woods period;

- The explicit monetarism of the mid-70s;

- The adoption of inflation targets in the early 90s;

- The implementation of monetary policy with standing facilities in the early 90s;

\section{The Establishment of the central bank:}

The core Western countries operating on the gold standard (e.g. the United States, the United Kingdom), all had central banks that held a monopoly over the note issue, and

\footnotetext{
${ }^{1}$ The US was following an inflationary policy that was inconsistent with the dollar being the central reserve currency. See Bordo (1993).

${ }^{2}$ The US data are used because they are easy to find; a more complete graphic would have inflation rates for G7 countries, but the picture would be broadly the same.
} 
performed to differing extents such functions as: clearing house, lender of last resort, central reserve depository. However, the gold standard operated as a nominal anchor, which severely constrained their ability to operate monetary policy.

Canada also held to the gold standard, but without a central bank. Notes were issued by competing private banks and, like central bank notes, were convertible into gold on demand. The government did issue a statutorily limited amount of notes in small denomination $(\leq \$ 5)$ notes, which comprised about $20 \%$ of the note issue, and 'large legals'. ${ }^{3}$ Both were legal tender and convertible into gold on demand. The government also operated a discount window at which the banks could borrow Dominion notes. The association of the chartered banks (CBA) operated the clearing house. While attempts to establish a central bank had been made at various times in Canadian history, the system appeared to function relatively well, so why create a central bank in 1934 ?

In a previous paper (Bordo and Redish, 1987), we argue that the primary reason was political expediency. A variety of constituencies argued in favour of a central bank: Western populists wanted to take the power to create money out of the grubby profitmaximizing hands of Eastern banks; others believed that a central bank would remove the potential power of money creation from the greedy hands of government. Academic economists argued that a central bank would "manage the currency and credit in the best interests of the Canadian economy", and would provide impartial economic advice to the government as well as facilitating greater international cooperation and policy coordination (McIvor, 1958; 144).

Ironically, one of the strongest arguments traditionally adduced for central banks - that they can be a necessary lender of last resort - was substantially weakened in the early 1930s when one third of US banks failed, while no Canadian bank failed. ${ }^{4}$ The Canadian Banker's Association argued against the establishment of a central bank on the grounds

\footnotetext{
${ }^{3}$ Data for 1913; MacIvor (1958: 67).

${ }^{4}$ Though we note the argument of Kryzanowski and Roberts (1993) that it is unclear whether this reflected financial soundness or regulatory forbearance.
} 
that note issue by the private (chartered) banks created elasticity in the money supply that enabled the Canadian system to handle shocks particularly well.

Perhaps the critical argument for a Canadian central bank was 'national pride'. The 1930s generally were a decade of assertive nationalism: the founding of TransCanada airlines (forerunner of Air Canada); the creation of the CBC; the Statute of Westminster, were three other features of this time. At two major international conferences designed to restore and maintain the international financial system, the International Finance Conference in Brussels in 1931 and the World Economic Conference in 1933, the major powers called on all developed economies to establish a central bank to provide the tools for international co-ordination. Finally Prime Minister Bennett, speaking in 1933, argued that he had in fact decided in December 1931 to establish a central bank:

"I learned to my surprise that there was no direct means of settling international balances between Canada and London, that the only medium was New York, and the value of the Canadian dollar would have to be determined in Wall St. I made up my mind then and there that this country was going to have a central bank."5

The Bank of Canada, then, was established to satisfy a political desire for government action during the most serious business cycle downturn Canada had experienced. The Bank expected that the gold standard would be re-established, perhaps in an environment of greater international co-ordination. ${ }^{6}$

\section{Floating in a sea of fixed currencies}

Canada had been an enthusiastic contributor to the Articles of Agreement that established the IMF. Canadian officials had argued that Canada would be a definite beneficiary if a stable system of exchange rates were established after World War II, rather than the returning to the somewhat chaotic exchange rate system of the late 1930s when some currencies were inconvertible and payments were cleared bilaterally rather than multilaterally.

\footnotetext{
${ }^{5}$ Cited in Stokes, 1969; 65.

${ }^{6}$ The Bank of Canada Act required that notes be convertible into gold on demand, with the provision that the government could suspend convertibility if it so desired, which it immediately did.
} 
The Canadian dollar was fixed against the US dollar during the war and in July 1946 was revalued to parity against the US dollar (see Figure 2). In late 1949, Canada joined Britain and a number of other countries in devaluing against the dollar, returning to the wartime 90.0 c rate. But through 1950, capital inflows generated by investment opportunities in the resource sector, and accelerated by the onset of the Korean war, led to a significant increase in international reserves. This in turn encouraged speculation that Canada would revalue generating short term capital inflow; in October 1950, the decision was made to float the dollar. The Minister of Finance (speaking in 1952) stated that "No one could decide with any reasonable assurance what new fixed rate could be maintained. We had no choice but to leave the rate free to find its own level in the market". ${ }^{7}$

The decision to float the currency in the absence of either fiscal exigency or financial crisis was possibly without precedent. The government argued - at least as rhetoric for allaying the concerns of the IMF - that the float was a transitory adjustment mechanism rather than the permanent adoption of a fiat money currency.

Surprisingly to some, the float itself was relatively tranquil - at least for the first decade. The Canadian dollar appreciated and by mid-1952 was at a $4 \%$ premium relative to the US dollar. It remained in the $\$ 1-\$ 1.05$ range through the 1950 s before depreciating well below parity with the onset of the Coyne affair. In that traumatic event in Canadian monetary history, when James Coyne, who had been Governor of the Bank of Canada since 1955 was dismissed in 1962 by Finance Minister Fleming for presiding over 5 years of poor economic performance. ${ }^{8}$ The stability of the currency over the decade became a key data point in the debate over fixed vs. flexible exchange rates that raged in the late 60 s and early 70s. Advocates of flexible rates argued that the Canadian experience showed that flexible rates would not necessarily bring the competitive devaluations and currency chaos of the 1930s. Speculation would tend to be stabilizing rather than destabilizing.

\footnotetext{
${ }^{7}$ Cited in Wonnacott $(1960 ; 58)$ fn.56.

${ }^{8}$ See Bordo and Schembri (2004).
} 
With hindsight there are a couple of caveats: Canada was a small open economy, and was operating in a larger world that had maintained its nominal anchor. The first, didn't require hindsight! Writing in 1935, Lionel Robbins had stated "While it may be quite possible, and not necessarily very harmful to the rest of the world, for small countries acting in isolation to attempt to solve their local problems by such expedients [i.e. flexible exchange rates], their general adoption in the big financial centres can only lead to perpetual confusion and instability". 9 Without necessarily buying into the second half of this statement, we can note that what works for a small open economy may not work for a global system.

Extending this argument, it is critical to contextualize the Canadian experience. We now know that having a nominal anchor can be a key ingredient for the successful monetary regimes. The Canadian experience, because it occurred in a world where the leading currencies were attached (albeit loosely) to gold, and because Canada emphasized its transitory nature, was not able to provide evidence about the need for a nominal anchor. Thus when flexible rates were widely adopted in the 1970s, it took time to develop monetary stability.

\section{Monetarism}

The 1970s have become known as the decade of the Great Inflation, and Canada like many other countries, including the UK and the US, experienced unprecedentedly high rates of inflation. Today, the causes/sources of the inflation are hotly debated, with blame being variously attributed to oil shocks, poor data, or poor economic models. In 1975, the Canadian CPI inflation rate hit $14 \%$ and the Canadian government responded. The government adopted price and wage controls and the Bank adopted monetarism as an anti-inflation policy. Monetarism in its purest form is associated with the $\mathrm{k} \%$ rule proposed by Friedman (1959). He argued that the combination of the lags in policy making, the imperfect information available to policy makers and the potential expediency of policy, implied that countries should adopt constitutional amendments that

\footnotetext{
${ }^{9}$ Cited in Wonnacott, 1960; 21.
} 
required a monetary aggregate to grow at a fixed rate annually, that rate being something like $5 \%{ }^{10}$

The end of Bretton Woods led many countries to search for a nominal anchor - a clear target for monetary policy, and as inflation rose many adopted variants of this monetarist prescription. The Bundesbank targeted reserves; the Bank of England targeted sterling M3; the Bank of Japan announced forecasts for M2 beginning in $1978 .^{11}$ The US announced targets for three monetary aggregates, but appeared to be more interested in monitoring monetary growth than targeting it. Bernanke and Mishkin (1992) argue that Fed policy was not particularly restricted by monetary targets before Volcker's announcement of a new commitment to combating inflation in October 1979. The Bank of Canada targeted M1 and chose a gradualist approach, starting with a target growth range for $\mathrm{M} 1$ of $10-15 \%$, and then over time lowering the range to $8-12 \%$ and then $4-8 \%$. Relative to the Fed., the Bank was much more committed to the monetarist rhetoric, at least in the Seventies. ${ }^{12}$

But the monetarist experiment was not a success. After an initial pause, inflation returned to double digit levels, this despite a growth rate of M1 less than the target rates for most of the 1975-80 period. Essentially, a potent combination of very high nominal interest rates, reflecting inflationary expectations, and the diffusion of computing power dramatically reduced the demand for demand deposits. ${ }^{13}$ Households switched from demand deposits to daily interest chequing accounts (which legally allowed the banks to claim 'notice' of withdrawals so were not demand deposits), while firms used sweeps to minimize their overnight balances. ${ }^{14}$

\footnotetext{
${ }^{10}$ That is, a rate that if accompanied by real growth of $3 \%$ pa and a fall in velocity of $2 \%$ pa would yield price stability.

${ }^{11}$ Bernanke and Mishkin (1992).

${ }^{12}$ Although see Bernanke and Mishkin's conclusion that the rather haphazard schedule for announcing new targets, and their base periods, implied a lack of commitment.

${ }^{13}$ Freedman $(1983,103)$ notes that "Unlike the situation in the United States, deregulation played absolutely no role in the developments in either the household or corporate sector." See also Courchane $(1983 ; 37-51)$.

${ }^{14}$ The differential reserve requirements (3\% for notice deposits, $10 \%$ for demand deposits) were undoubtedly a factor in the banks' strategy. See Courchene (1983; 44).
} 
In November 1982, arguing that 'the targets abandoned us', the Bank officially ended M1 targeting. Yet Figure 1 shows that by 1983 inflation had been, well if not vanquished, at least brought under control. What ended the 'Great Inflation of the 1970s'? There was no clear replacement for the policy target, and indeed there would be no new paradigm until the introduction of inflation targeting in the early 90s. The general consensus is that the Bank of Canada piggy-backed on the US anti-inflation policies by adopting an implicit exchange rate target. As the US raised interest rates, and the US dollar appreciated, Canada chose to follow US rates up. The result was a negative rate of real money growth (M2), a 4\% decline in real GDP, and a fall in inflation from $12.5 \%$ in 1981 to $5.8 \%$ in 1983 .

\section{Inflation Targets. $^{15}$}

In February 1991, the Minister of Finance and the Bank of Canada jointly announced that the Bank would target the CPI inflation rate. At the time the inflation rate was close to $6 \%$ and a target of $3 \%$ inflation (to be gradually reduced) was announced. Inflation targeting has been broadly successful. Whereas in past decades monetary policy has been controversial and has generated heated debate in the literature, today, there is broad acceptance - possibly disinterest - amongst Canadians about the conduct of monetary policy.

Ironically, it was Governor Bouey who (in 1982) spoke of "finding a place to stand", because that is precisely what inflation targeting has provided. But it is important to remember what inflation targeting isn't. Inflation targets are not necessary to cause disinflation, or even to stabilize inflation; as noted earlier, the US has a similar inflation history without explicit inflation targets. Inflation targets were not involved either in the end of the Great Inflation of the 70s, a much more critical anti-inflation step. Nor is there much evidence that they made the decline in inflation less expensive in terms of unemployment. ${ }^{16}$ It should also be emphasized - as the Bank has on many occasions -

\footnotetext{
${ }^{15}$ The Bank of Canada was not the first central bank to adopt inflation targets - the Reserve Bank of New Zealand adopted inflation targets in March 1990.

${ }^{16}$ Robson and Laidler (1993; 137-7).
} 
that inflation targeting is not inconsistent with a concern for employment (as required by the Bank Act).

What is inflation targeting? As conducted in Canada it is an explicit commitment by the Bank of Canada to orient policy to attain a particular rate of growth of the CPI, currently $2 \%$. The tools that the Bank uses to attempt to attain that goal include (a) using a projection model to determine what over-night interest rate would be consistent with a $2 \%$ inflation rate within 8 quarters, and setting the target for the overnight rate at that level, ${ }^{17}$ and (b) a communications strategy. There has been a dramatic change in the transparency of monetary policy between 1995 and 2000. This is probably most starkly put by noting that in 1994, individuals in the economy had to guess that the Bank had changed its monetary policy stance - there was no announcement. For example, Laidler and Robson (1993) describe how "students of the Bank of Canada's actions" may want to look at the T-Bill -overnight rate spread as an indicator of the stance of monetary policy. There were no announcements; there was no Monetary Policy Report; the market would learn that the Bank's policy had changed because the Bank was intervening (PRA/SPRA) at a different rate than yesterday morning.

Have we come full circle? Have we just switched anchors? At the beginning of the $20^{\text {th }}$ century, the gold standard provided a nominal anchor to the monetary system, and central banks were seen as handmaidens to the gold standard, that could ease necessary adjustments and facilitate international co-operation. There is a broad congruence inflation targets provide a visible, comprehensible, characterization of the monetary regime - but there are definite limits to the parallels.

- the gold standard evolved over centuries, and its credibility reflected that history;

- the gold standard was, in an important way, an automatic system; inflation targets require greater skill;

- the gold standard was closer to a price level than inflation target since it did not incorporate base drift;

\footnotetext{
${ }^{17}$ In the language of Courchene (1976) the instrument of policy is the overnight rate, and the intermediate target is the forecast of the inflation rate.
} 
- most significantly, the gold standard was an anchor that could shift arbitrarily (with gold discoveries) and which imposed real resource costs; fiat money avoids these disadvantages.

\section{Implementation of monetary policy using standing facilities}

The mechanisms for implementing monetary policy have evolved gradually over the decades, but the changes in the 1990s were sufficiently important that they merit special mention. These changes include:

- the phase out of reserve requirements (1992-94) ${ }^{18}$;

- the shift from focusing on the 3 month Treasury bill rate to setting a 50 basis point range for the overnight rate (mid-'94); implemented by manipulating the supply of settlement balances using changes in the amount of government funds on deposit and open market operations;

- first issue of the monetary policy report (May 1995);

- setting the Bank rate as the top of the overnight rate target range (rather than having it tied to the T-Bill rate) and issuing press releases to announce changes in the target;

- introduction of Large Value Transfer Settlement system, LVTS, (February 1999) - see below;

- introduction of 'fixed dates' for monetary policy announcements (2000).

In the 1990s, the majority of large economies moved from a Deferred Net Settlement system to a real-time gross settlement system, primarily to give real time finality to large payments and reduce systemic risk. In Canada, the LVTS came on-line in 1999, and at the same time the Bank also began paying interest on reserves. Direct clearers (mainly the large banks and trust companies) now operate in an environment where the Bank provides (a) an infinitely elastic supply of reserves (collateralized) at the Bank rate defined as $25 \mathrm{bp}$ above the target for the overnight rate; and (b) an infinitely elastic

\footnotetext{
${ }^{18}$ This change - the reduction of the required reserve ratio to zero - was less radical than it might appear. By the mid-90s, the high demand for currency to stock ATMs, which also of course could be used to satisfy reserve requirements, combined with the stagnant demand for demand deposits, meant that the existing ratio was barely binding.
} 
demand for deposits paying interest at the overnight rate less $25 \mathrm{bp}$. The spread (which far exceeds the bid-ask spread on overnight loans of about 10-12bp) is wide enough to encourage the market for overnight funds to clear without using either of these two facilities.

The net effect of the elimination of reserve requirements, introduction of LVTS and payment of interest on reserves has been to streamline the operation of monetary policy. The overnight rate stays very close to the target - far closer than in for example the United States (Woodford, 2000), and a tax that distorted a wedge between financial institutions and between different liabilities of the same institution has been eliminated.

\section{Conclusion:}

The Bank of Canada has been in operation for just over 70 years and has seen dramatic changes in the Canadian economy, in the structure of international finance, and in the nature of money. The change in the balance sheet of the Bank between March 1935 and March 2005 (see Table 1) highlights some of the changes - the absence of gold on the asset side, the absence of bank reserves on the liability side. Yet, as noted earlier, there is also remarkable continuity in its mission.

The current monetary situation would appear as calm as any that the Bank has experienced, but we should beware of complacency. The history of the Bank is one of being buffeted by both sharp crises and slower moving evolutionary forces. One hundred years ago, in 1905, the gold standard was working smoothly and the Canadian economy growing robustly. But the financial crisis of 1907, and the cataclysm of 1914 were not far distant. It is of course difficult to foresee the particular direction from which threats to the stability of the monetary system may come, but that they will come cannot be in doubt.

Meantime, the environment in which the Bank operates continues to evolve, and the forces of globalization and technological change (and the nature of the state) which have driven the evolution of central banking will largely determine the look of the Bank in another 70 years. 


\section{References}

Bernanke, B. and F. Mishkin, (1992), "Central Bank Behaviour and the Strategy of Monetary Policy: Observations from six industrialized countries" in O.J. Blanchard and S. Fischer eds., NBER Macroeconomics Annual 1992. Cambridge, Mass.: MIT Press.

Bordo, M. (1993) "The Bretton Woods International Monetary system: An Historical overview" in M. Bordo and B. Eichengreen eds., A Retrospective on the Bretton Woods system Chicago: University of Chicago Press.

Bordo, M. and L. Schembri, (2004), “Canada's Floating Rate in the 1950's: Was Milton Friedman Right and James Coyne Wrong?” Bank of Canada (mimeo) July.

Bordo, M. and A. Redish, (1987), "Why did the Bank of Canada emerge in 1935?" Journal of Economic History, v. 47: 405-17.

Bouey, G. (1982) "Monetary Policy - Finding a place to stand" Bank of Canada Review, Sept. 1982.

Courchene, T. (1976) Money, Inflation and the Bank of Canada: An Analysis of Canadian Monetary Policy from 1970 to early 1975. Montreal: C.D. Howe Institute.

Courchene, T. (1983) No Place to Stand? Abandoning monetary targets: an evaluation. Toronto: C.D. Howe Institute.

Freedman, C. (1983) "Financial Innovation in Canada: Causes and Consequences" Amercian Economic Review 67 (May): 101-6.

Friedman, M., (1959) A Program for Monetary Stability. New York: Fordham University Press.

Kryzanowski, L. and B. Roberts (1993) “Canadian Bank Solvency, 1922-40” Journal of Money Credit and Banking, vol. 25: 361-76.

Laidler, D. and W. Robson, (1993) The Great Canadian Disinflation: The Economics and politics of monetary policy in Canada, 1988-93. Toronto: CD Howe Institute.

MacIvor, R.C., (1958), Canadian Monetary, Banking and Fiscal Development. Toronto: Macmillan Company of Canada. 
Redish, A. (1993) "Anchors Aweigh: the transition from commodity money to fiat money in Western Economies" Canadian Journal of Economics 26 (November): 777-95.

Stokes, M.L., (1939), The Bank of Canada. Toronto: Macmillan Company of Canada.

Wonnacott, P., (1960), The Canadian Dollar, 1948-58. Toronto: University of Toronto Press.

Woodford, M. (2000), Monetary Policy in a world without money" International Finance vol.3: 229-260. 
Figure 1

Seventy Years of (CPI) Inflation

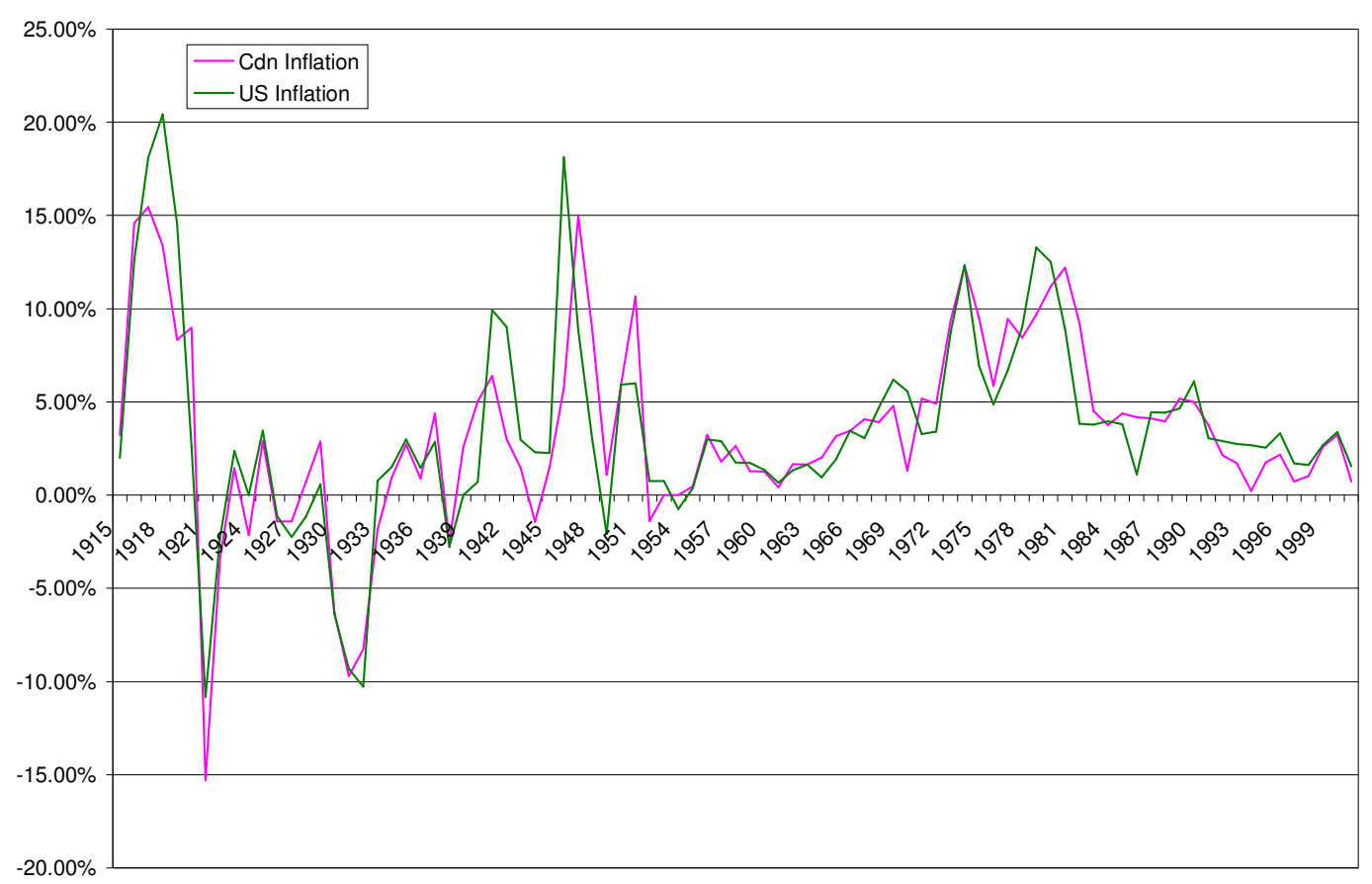

Source: Cansim I: US - D139105; Canada - P100298; Both series, CPI in levels; December observations. Rate of change calculated. 
Figure 2

Price of a \$US (in C\$)

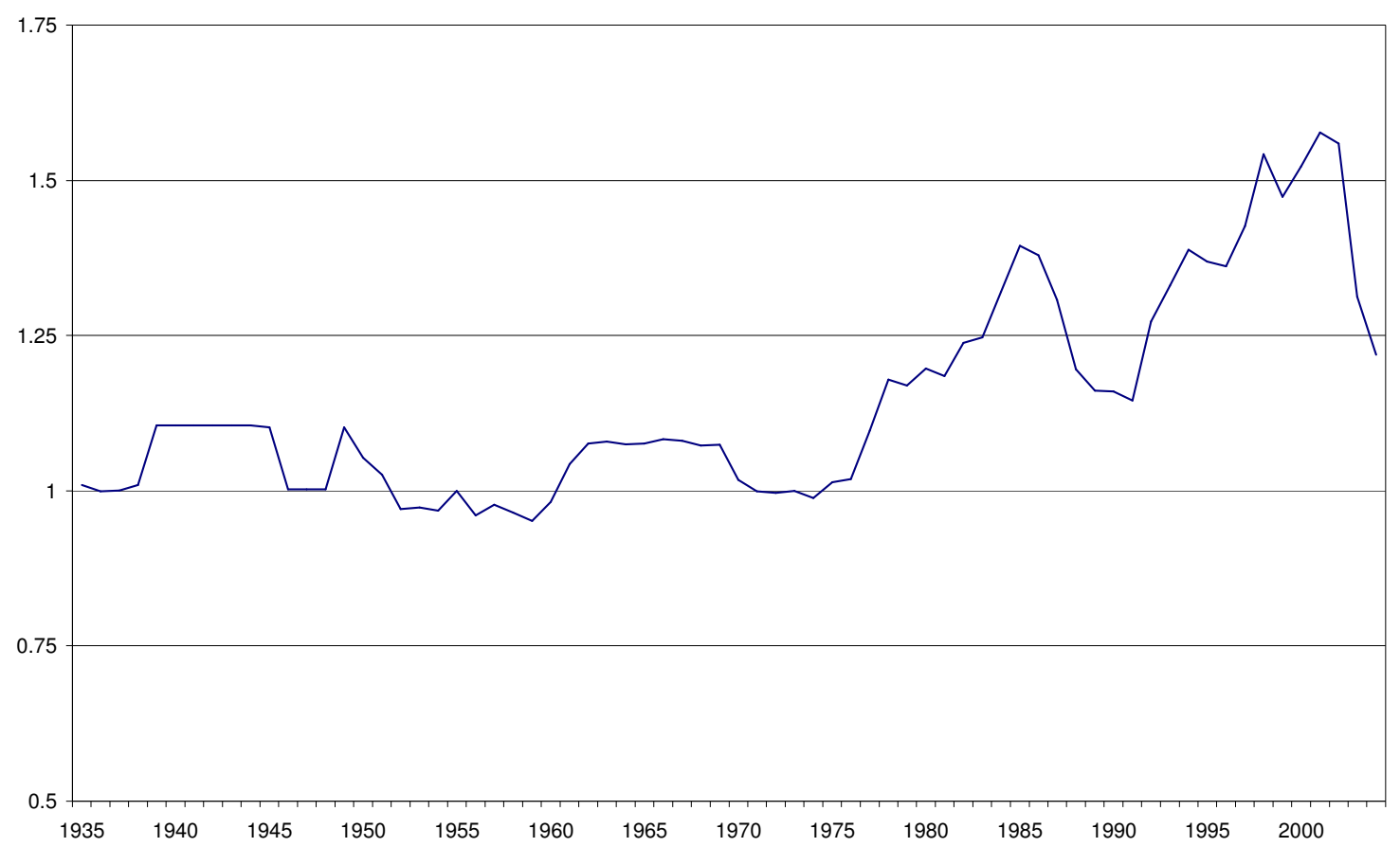

Source: 1950 on, Cansim II: V37426 Noon spot rate; December observation. Before 1950 - Bank of Canada Statistical Summary, various years. 
Table 1

\section{Balance Sheet of the Bank of Canada}

March 1935

(\$millions)

Assets:

Gold

Government Securities

Miscellaneous

Total

$\underline{269}$

106

152

11

\section{March 2005}

(\$billions)

Assets:

Government Securities

Miscellaneous

\section{Liabilities:}

Notes (incl. 3 in banks)

41.7

Government deposits

Misc.

45

51

149

24

$\underline{269}$

Total

$\underline{43.8}$

Total

$\underline{43.8}$

Note: The ratio of Bank of Canada assets to GDP was 6\% in 1935, and 3\% in 2004.

Source: Bank of Canada Statistical Summary, and Bank of Canada website. 